\title{
Anti-diabetic and hypolipidaemic effect of botanicals: a review of medicinal weeds on KNUST campus, Kumasi
}

\author{
Christopher Larbie*, Dennis Torkornoo and Jeffrey Dadson \\ Department of Biochemistry and Biotechnology, Kwame Nkrumah University of Science and Technology, Kumasi, Ghana.
}

\begin{tabular}{ll} 
ARTICLE INFO & ABSTRACT \\
\cline { 3 - 3 } $\begin{array}{l}\text { Article history: } \\
\text { Received on: } 16 / 07 / 2014\end{array}$ & $\begin{array}{l}\text { In recent times, weeds have been controlled by chemical means and other means because they are seen as plant } \\
\text { pests as they compete with "useful" plants for shelter, sunlight, nutrients and water. However, these weeds can } \\
\text { Accepted on: } 24 / 08 / 2014\end{array}$ \\
$\begin{array}{l}\text { Available online: } 30 / 10 / 2014 \\
\text { serve as medicines for the treatment of several diseases such as diabetes and hyperlipidaemic conditions. This } \\
\text { review, therefore creates the awareness of some weeds on KNUST campus, Kumasi-Ghana, which are capable of } \\
\text { treating diabetes and hyperlipidaemia. There were sixteen weeds from 11 different families identified with anti- } \\
\text { hyperls: } \\
\text { heeds }\end{array}$ & $\begin{array}{l}\text { such as malaria, toothache, eye problems, among others. Conclusion can therefore be drawn that weeds are } \\
\text { valuable medicinal plants and hence, must be preserved. }\end{array}$ \\
\hline
\end{tabular}

\section{INTRODUCTION}

The occurrence of weeds is a serious problem in agriculture and tremendously reduces the productivity of agricultural trends by competing with crops for water, mineral nutrients, space and light (Sahu, 1983). A weed, in a general sense, is a plant usually wild or feral that is commonly considered to be a nuisance in a garden, lawn, or other agricultural development. More specifically, the term is often used to describe plants that grow and reproduce aggressively (Ediriweera, 2007). Weeds are now widely regarded as pests of crop because they lower the yield and increase the cost of production in various ways. Weeds, however, are also helpful to human beings in several ways among which are food, erosion control, medicine, supply of organic matter and mineral nutrients to soil, among others (Maroyi, 2011).Recent developments have revealed the importance of weedy species in traditional medicine. For instance, in Kenya, 75 plant species from 34 families are used to cure 59 ailments in traditional medicine of Central Kenya (Lewu and Afolayan, 2009). According to the WHO, over $80 \%$ of the world's population relies on traditional forms of medicine, largely plant based to meet primary health care needs (Mazid et al., 2012).

* Corresponding Author

Email:: ekowlarbie@gmail.com
Weeds are capable of curing so many diseases due to the presence of phytochemicals, among these diseases are diabetes and hyperlipidaemia.

Hyperlipidaemia is a highly predictive risk factor for atherosclerosis, coronary artery diseases, cerebral vascular diseases and a primary cause of death. The characteristic expression of hyperlipidaemia is an elevation in the plasma concentration of cholesterol and/or triglycerides (Desu and Saileela, 2013).Diabetes mellitus (DM) is a metabolic disorder characterized by elevation of blood glucose level.

DM is found worldwide and becoming a serious threat to mankind. It is third killer of human beings after cancer, cardiovascular and cerebro-vascular diseases (Gupta et al., 2009). Recently, some medicinal plants have been reported to be useful in hyperlipidaemia and diabetes worldwide and have been used empirically as anti-hyperlipidaemic and antidiabetic remedies. According to Kim et al. (2008), more than 400 plant species having hyperlipidaemic and anti-diabetic activities are available in literature.

This review was undertaken to discuss medicinal weeds on KNUST campus with anti-hyperlipidaemic and anti-diabetic activities, to serve as a guide for further research and also to persuade the conservation of such weeds with due consideration and proper planning. 
Table 1: Summary of medical plants on KNUST Campus with anti-diabetic and anti-hyperlipidaemic activities.

\begin{tabular}{|c|c|c|c|c|c|}
\hline Plant & Family & Part used & Extract studied & $\begin{array}{c}\text { Diabetic } \\
\text { /hyperlipidaemic } \\
\text { inducing agent }\end{array}$ & $\begin{array}{c}\text { Biochemical } \\
\text { /histopathologicalparameters } \\
\text { studied }\end{array}$ \\
\hline Ageratum conyzoides $\mathrm{L}$. & Asteraceae & $\begin{array}{l}\text { Whole plant } \\
\text { and leaves }\end{array}$ & Aqueous extract & Streptozotocin & Oral glucose tolerance \\
\hline Bauhinia rufescens Lam. & Fabaceae & Leaves & Methanolic extract & Alloxan & $\begin{array}{l}\text { Blood glucose, lipid profile and } \\
\text { body weight }\end{array}$ \\
\hline Cassia auriculata $\mathbf{L}$. & Fabaceae & Flowers & Aqueous extract & Streptozotocin & $\begin{array}{l}\text { Blood glucose, haemoglobin, } \\
\text { glycosylated haemoglobin, serum } \\
\text { and tissue lipids, hexokinase and } \\
\text { glucose-6-phosphatase activity }\end{array}$ \\
\hline Gongronema latifolium & Asclepiadaceae & Leaves & $\begin{array}{l}\text { Aqueous and } \\
\text { Methanolic extract }\end{array}$ & Alloxan & Phytochemicals and $\mathrm{LD}_{50}$ \\
\hline Hyptis suaveolens (L.) Poit & Lamiaceae & Leaves & Aqueous extract & Streptozotocin & $\begin{array}{l}\text { Triglyceride, total cholesterol, low } \\
\text { density lipoprotein, very low } \\
\text { density lipoprotein }\end{array}$ \\
\hline Ipomoea sepiaria Roxb. & Convolvulaceae & Leaves & Aqueous extract & Streptozotocin & Serum glucose concentration \\
\hline Mimosa pudica $\mathbf{L}$. & Fabaceae & Leaves & $\begin{array}{l}\text { Ethanolic and } \\
\text { petroleum ether } \\
\text { extract }\end{array}$ & Alloxan & Plasma glucose level \\
\hline Mollugo nudicaulis Lamk. & Molluginaceae & Whole plant & Ethanolic extract & Alloxan & $\begin{array}{l}\text { Blood glucose, cholesterol, } \\
\text { triglycerides, LDL, lipid } \\
\text { peroxidation, liver glycogen, serum } \\
\text { creatinine, urea, uric acid and liver } \\
\text { marker enzymes such as AST, } \\
\text { ALT, ALP }\end{array}$ \\
\hline Pergularia daemia (Forsk.) Chiov. & Apocynaceae & Whole plant & $\begin{array}{l}\text { Methanol and } \\
\text { aqueous extract }\end{array}$ & Alloxan & Blood glucose \\
\hline Phyllantus amarus Schum. \&Thonn. & Euphorbiaceae & Leaves & Ethanolic extract & Alloxan & $\begin{array}{l}\text { Blood glucose, liver enzymes such } \\
\text { as glucokinase, glucose -6- } \\
\text { phosphatase and fructose -1- 6- } \\
\text { diphosphatase }\end{array}$ \\
\hline Senna occidentalis $\mathbf{L}$. & Fabaceae & Leaves & Methanol & Streptozotocin & $\begin{array}{l}\text { Blood glucose, Haemoglobin, } \\
\text { glycosylated haemoglobin, hepatic } \\
\text { glycogen, lipid peroxidation, } \\
\text { antioxidants enzymes (TBARS, } \\
\text { HP, SOD, CAT, GPx, VitC, Vit } \\
\text { E,GSH) and hepatic marker } \\
\text { enzymes (ALT, AST,ALP,ACP) }\end{array}$ \\
\hline Sida acuta Burm.f. & Malvaceae & Leaves & $\begin{array}{l}\text { Aqueous and } \\
\text { methanol extracts }\end{array}$ & Alloxan & Blood glucose \\
\hline Vernonia amygdalina Delile & Asteraceae & Leaves & Ethanolic extracts & Streptozotocin & $\begin{array}{l}\text { Glucose and activities of } \\
\text { antioxidant enzymes, e.g., catalase } \\
\text { (CAT), glutathione peroxidase } \\
\text { (GPx) and superoxide dismutase } \\
\text { (SOD) }\end{array}$ \\
\hline Catharanthus roseus (L.) G. Don & Apocynaceae & Leaves & Powder & Streptozotocin & Plasma glucose, plasma insulin \\
\hline & & & & & $\begin{array}{l}\text { Blood glucose, serum cholesterol, } \\
\text { serum triglyceride, high density }\end{array}$ \\
\hline Amaranthus viridis $\mathbf{L}$. & Amaranthaceae & Leaves & Methanolic extract & Streptozotocin & $\begin{array}{l}\text { lipoprotein, low } \\
\text { lipoprotein, very low density } \\
\text { lipoprotein }\end{array}$ \\
\hline Euphorbia prostrate Aiton & Euphorbiaceae & Whole plant & Ethanolic extract & $\begin{array}{l}\text { Atherogenic } \quad \text { diet }+ \\
\text { cholesterol } \\
\text { supplement }\end{array}$ & HDL-cholesterol, lipid profile \\
\hline
\end{tabular}

\section{Medicinal weeds with anti-diabetic and anti-hyperlipidaemic activity}

Table 1 above gives the summary of 16 weed plants identified with anti-diabetic and anti-hyperlipidaemic on KNUST campus. Each plant is described in the remaining sections.

\section{Ageratum conyzoides L. (Asteraceae)}

Common names: Billygoat-weed, Goatweed, Whiteweed or Chickweed (Nyunai et al., 2010).

\section{Description}

It is an annual herb ramified and up to $1 \mathrm{~m}$ tall. Its stem and leaves are covered with tiny white hairs. Leaves are opposite, pubescent with long petioles and include glandular trichomes. The flowers are purple and white and the fruits are black and easily dispersed (Nyunai et al., 2010).

Parts used: Whole plant and leaves.

Medicinal uses: Pharmacological studies have revealed that the plant has anti-diarrhoeal and antibacterial, antiparasitic, 
anti-inflammatory anticoagulant, myorelaxant, haemostatic, analgesic, antifungal and hypothermic properties. In traditional medicine, a decoction or infusion of $A$. conyzoides is used for the treatment of constipation, hepatitis, eczema, epilepsy, wounds, dizziness, diarrhoea, vomiting, fever, headaches, intestinal worms and filariasis. Fresh leaf aqueous extract is used in treating painful menstruation, itching of eye and against lice. An ethno-botanical study reported that, leaves, or entire plant decoction is useful for the treatment of diabetes (Nyunai et al., 2010). The hypoglycaemic and anti-hyperglycaemic properties of the aqueous extracts of the leaves of A.conyzoides L. have being validated in normo- and hyperglycaemic rats (Nyunai et al., 2010).

Toxicity

The plant has been reported to have hepatotoxic activities. It contains pyrrolizidine alkaloids and echinatine which form covalent bonds with nucleic acids of the hepatocytes to disrupt cellular protein synthesis and replication which cause liver lesions and tumours (Fu et al., 2002).

\section{Bauhinia rufescens Lam. (Fabaceae) Description}

B.rufescens is a shrub usually 1-3 m high and sometimes reaching $8 \mathrm{~m}$. The bark is ash-grey, smooth and very fibrous. The leaves are very small with greenish-yellow to white and pale pink flowers. Fruits aggregated with 4-10 seeds each (Muhammad and Sirat, 2013).

Parts used: Whole plant, roots and leaves.

\section{Medicinal uses}

The plant is used in the treatment of gout, gingivitis, diarrhoea, dysentery, diabetes, leprosy and malaria. The leaves and fruit are for the treatment of diarrhoea, dysentery and ophthalmic diseases. An extract of the root is used as an astringent or antipyretic. The bark of the roots and trunk is used to cure chest complaints, syphilis and other venereal diseases and to reduce fever (Muhammad and Sirat, 2013). An investigation carried out by Aguh et al. (2013), showed that methanolic leaf extracts of Bauhinia rufescens has beneficial effects on diabetic hyperlipidemia as such could be advanced in preventing the development of atherosclerosis and possible related cardiovascular pathologies associated with diabetes.

\section{Cassia auriculata L. (Fabaceae) \\ Common name: Tanner's cassia Description}

C.auriculata is a much branched shrub with smooth cinnamon brown bark and closely pubescent branchlets. The leaves are alternate, stipulate, paripinnate compound, very numerous, closely placed. Its flowers are irregular, bisexual, bright yellow and large. The fruit is a short legume, oblong, obtuse, tipped with long style base, flat, thin, papery, undulately crimpled, pilose, pale brown (Anushia et al., 2009).

Parts used: Roots, leaves, flowers and seeds.

Medicinal uses: This plant is said to contain a cardiac glucoside (sennapicrin) and sap, leaves and bark yield anthraquinones, while the latter contains tannins. The root is used in decoctions against fevers, diabetes, diseases of urinary system and constipation. The leaves have laxative properties. The dried flowers and flower buds are used as a substitute for tea in case of diabetes patients. The powdered seed is also applied to the eye, in case of chronic purulent conjunctivitis. In Africa, the bark and seeds are said to give relief in rheumatism, eye diseases, gonorrhoea, diabetes and gout. The plant has been shown to have antibacterial activity in laboratory animals (Anushia et al., 2009). A study conducted by Pari and Latha, (2002) onCassia auriculata flower extract (CFEt), at doses of $0.15,0.30$ and 0.45 $\mathrm{g} / \mathrm{kg}$ body weight for 30 days, observed the suppression of elevated blood glucose and lipid levels in diabetic rats. C.auriculata at $0.45 \mathrm{~g} / \mathrm{kg}$ was found to be comparable to glibenclamide. These findings indicate that the C.auriculata flowers possess antihyperlipidaemic effect in addition to antidiabetic activity.

\section{Gongronema latifolium (Asclepiadaceae) Description}

This is a climbing shrub with hollow stems and fleshy roots, containing latex. Leaves are opposite, simple and entire with petioles. Its blade is broadly ovate, base deeply cordate, apex acuminate, papery. Inflorescence is terminal and axillary cymose panicle. Flowers are bisexual, small, 5-merous, regular, yellowgreen, and fragrant; calyx lobes elliptical to rounded, hairy at apex (www.prota4u.org).

Parts used: Whole plant, leaf and stem bark

Medicinal value: G.latifolium is reported to have antiinflammatory, antibacterial, antioxidant, anti-asthmatic and antiplasmodal activities. The leaf extracts have analgesic effects, antipyreticand anti-sickling activities. The stem bark extracts have anti-ulcerative property. It is used to treat malaria, stomach disorders, diabetes, hypertension, muscular pains, arthritis and inflammation, cough and loss of appetite.

It has also been reported that the plant is used for the treatment of sore gums, colic, dyspepsia and anthelmintic, worm infections and for maintaining healthy blood glucose level. The plant contains phytochemicals such as polyphenols, alkaloids, glycosides, flavonoids, terpenes, tannins, saponins, alkaloids, $\beta$ sistosterol, lupenyl esters, pregnane ester and essential oils (Nnodim et al., 2012).Work done by Akah et al., (2011) showed the presence proteins, flavonoids, saponins, alkaloids, terpenoids, and steroids in methanol extract and fractions giving credence to the use of G. latifolium in the management of diabetes mellitus.

\section{Hyptis suaveolens (L.) Poit (Lamiaceae) \\ Common name: Pignut or Chan \\ Description}

It is an annual to perennial subshrub which grows up to $2 \mathrm{~m}$ high having branches and long white piliferous stems, its flowers are purple, the leaves are ovate with serrulate margins; the flowers are whorly arranged and the fruits are broadly obovoidal (Attawish et al., 2005; Deshmukh, 2012). 
Part used: Leaves

Medicinal uses: The leaves serve as antiseptic, sudorific, galactagogue and antidiabetic. The essential oils have mild antifungal activity against Candida albicans and Aspergillus niger. Phytochemicals present are alkaloids, glycosides, phytosterols, saponins, phenolic compounds and tannins (Attawish et al., 2005; Deshmukh, 2012).

A significant reduction in blood glucose was observed in diabetic animals treated with $H$. suaveolens at different doses when compared with diabetic rats. Levels of triglyceride, total cholesterol, low density lipoprotein, very low density lipoprotein were decreased. The results therefore showed that $H$. suaveolens possesses significant antihyperglycemic activity which might be attributed to stimulating effects on glucose utilization and antioxidant enzyme (Mishra et al.,2011).

Ipomoea sepiaria Roxb. (Convolvulaceae)Synonym: Ipomoea aquatica

Common name: Purple Heart Glory Description

It is a perennial slender herb with hairy stems; the leaves are simple, alternate, petiolate, ovate to cordate in shape; the flowers pale purple and subumbellate axillary cymes and the fruits are void (Das et al., 2011; Sayani et al., 2012).

Parts used: Whole plant, leaves and roots.

\section{Medicinal uses}

The root is used in the treatment of leucorrhoea and infertility. Whole plant serves as a tonic, aphrodiasiac, antidiuretic, antidiabetic and hyperdipsia. The leaves have antibacterial activity. The phytochemicals reported to be present are carbohydrates, alkaloids, glycosides, flavonoids, phenolic compounds, tannin and saponin (Das et al., 2011; Sayani et al., 2012).

The antidiabetic effect has been studied in streptozotocin induced diabetic Wistar rats, and Type II diabetic patients. The results revealed that consumption of the shredded, fresh, edible portion of I. aquatica for one week, effectively reduced the fasting blood sugar level of streptozotocin-induced diabetic rats $(\mathrm{p}=$ 0.01). When subjected to a glucose challenge, the Type II diabetic subjects showed a significant reduction $(\mathrm{p}=0.001)$ in the serum glucose concentration $2 \mathrm{~h}$ after the glucose load. However, it was not significantly reduced at $1 \mathrm{~h}(\mathrm{p}<0.09)$ post glucose load. There was a $29.4 \%$ decrease in the serum glucose concentration of the diabetic patients when treated with the plant extract (Malavidhane et al., 2003).

\section{Mimosa pudica L. (Fabaceae) \\ Common Name: Touch- Me-Not Description}

It is a prickly perennial herb that grows up between 0.5 $0.9 \mathrm{~m}$ high; leaves are bi-pinnate, opposite, compound in nature and sensitive to touch; flowers are axillary positioned, clustered in fluffy balls, radially symmetrical and campanulate; fruits occur in aggregate of 2-8 pods (Srivastava et al., 2012).

Parts used: Root, leaf and whole plant

\section{Medicinal uses}

The root extract is used to treat leprosy, dysentery, asthma, insomnia, premenstrual syndrome, menorrhagia, jaundice, impotence and haemorrhoid. The leaves are used to treat type-I diabetes. The whole plant is used to treat asthma (Srivastava et al., 2012). In a study conducted by Sutar et al. (2009), attempts were made to study anti-diabetic activity ofthe leaves of Mimosa pudica Linn. ethanolic extract showedsignificant decrease in blood glucose level whichcompared well with metformin as standard drug $(500 \mathrm{mg} / \mathrm{kg})$ in alloxan-induced $(150 \mathrm{mg} / \mathrm{kg})$ diabetic rats.

\section{Mollugo nudicaulisLamk.(Molluginaceae) \\ Common name: Daisey-leaved chickweed Description}

It is an annual plant which grows up to $22 \mathrm{~cm}$ tall. Leaves are broad, spathulate to oblanceolate, glabrous, and attenuate. Flowers are in dichasial cymes; scapes slender, glabrous; involucral bracts ovate-oblong, scarious; sepals oblong, mucronate, imbricate persistent. Filaments are persistent. Ovary is sub-globose. Seeds are muricate, minutely strophiolate, black and shiny (Sindhu et al., 2010).

Parts used: Whole plant.

\section{Medicinal value}

Mollugo nudicaulisis a medicinal herb, used by traditional practitioners to cure whooping cough, jaundice, cold, cough, fever, body pain and wounds. It is useful mainly in preventing small ring worms in stomach, to control diabetes and to increase the life energy of blood cells (Sindhu et al., 2010). The antidiabetic and antioxidant potential of $M$. nudicaulis whole plant ethanol extract has been demonstrated in alloxan-induced diabetic rats. At a dose $200 \mathrm{mg} / \mathrm{kg}$ administered orally to the diabetic rats for 21 days, significant decreases in the level of blood glucose, cholesterol, triglycerides, low densitylipoprotein (LDL), lipid peroxidation, liver glycogen, serum creatinine, urea, uric acidand liver marker enzymes such as AST, ALT, ALP were observed. It also produced significant increasein high density lipoprotein (HDL), superoxide dismutase (SOD), catalase (CAT), glutathione peroxidase (GPx), glutathione-S-transferase (GST), reduced glutathione(GSH), and Vitamin $\mathrm{C}$, which clearly showed the antioxidant property of extract(Sindhu et al., 2010).

\section{Pergularia daemia(Forsk.) Chiov. (Apocynaceae) Description}

It is a perennial herbaceous plant; the leaves are opposite, simple and broadly ovate to cordate with petioles (www.plants.jstor.org).

Part used: Whole plant

Medicinal uses: The whole plant serves as antidiabetic, laxative, antimalarial, anthelmintic, anti-pyretic and analgesic (Suresh Kumar and Mishra, 2008). Phytochemicals reported to be present are alkaloids, steroids, saponins, terpenoids and flavonoids (www.plants.jstor.org). 
A study to evaluate the antidiabetic activities of methanol and aqueous extracts of P.daemiain alloxan induced diabetic rats showed that oral administration of alcoholic extract of $P$. daemialeaves to diabetic rats for 21 days significantly reduced the levels of blood glucose levels in both acute and sub-acute study. The results were suggestive that the methanol extract of $P$. daemiapossess antidiabetic effect on alloxan induced diabetic rats and it can be recommended for the prevention of diabetes mellitus (Doss and Anand, 2014).

\section{Phyllantus amarusSchum. \&Thonn. (Euphobiaceae) \\ Common names: Stonebreaker or seed-under-leaf Description}

$P$. amarus is a small pantropical herb that grows to about $50 \mathrm{~cm}$. Leaf is in one plane. Flowers are all pendent from one side of the branch, separate male and female. Fruits globular-depressed, splits into 3 seeds ribbed (Khan et al., 2012). .

Part used: Whole plant

\section{Medicinal uses}

$P$. amarus is a potential diabetic and hypotensive drug for humans (Khan et al., 2012). Whole plant is used in the traditional and folk medicines for the treatment of jaundice, asthma, hepatitis, tuberculosis, ulcer and urinary diseases. It is also used in stomach ailments like dyspepsia, colic, diarrhoea, dysentery, dropsy, urinogenital problems, kidney stones, gall stones and for external application in case of swelling and inflammation (Xavier et al., 2012).

Oral administration of ethanolic leaf extract $(400 \mathrm{mg} / \mathrm{kg}$ body weight) for 45 days resulted in a significant $(\mathrm{P}<0.05)$ decline in blood glucose from 310.20 to $141.0 \mathrm{mg} / \mathrm{dl}$ and significant recovery in body weight of diabetic mice. There was also a significant $(\mathrm{P}<0.05)$ reduction in the activities of glucose-6-phosphatase and fructose-1-6-bisphosphatase in liver, significant $(\mathrm{P}<0.05)$ increase in the activity of glucokinase in liver of diabetic mice when compared with that of diabetic control. The study clearly shows that the ethanolic leaf extract of P.amarus possesses potent antidiabetic activity (Shetti et al., 2012).

\section{Senna occidentalis L. (Fabaceae) Synonym: Cassia occidentalis L. \\ Common Name: Coffee weed Description}

It is a slightly branched half wood annual herb that can grow up to a height of $8 \mathrm{~m}$. The leaves are compound alternate, pinnate, ovate at the top; the inflorescences are axillary raceme with yellow-coloured flowers (petals). The fruit exist as pod containing the seeds (Vashishtha et al., 2009).

Parts used: Whole plants, root, flower.

\section{Medicinal uses}

The roots treat ringworm, and snake bites. The leave/root extracts are used to treat jaundice, hepatitis, cirrhosis, and diabetes. The seed is used to treat asthma. Flower is used to treat bronchitis. The plant is used to inhibit bacteria, fungi and expel worms (Yadava and Satnami, 2011; Sadiq et al., 2012; Vashishtha et al., 2009).

In a study,methanol fraction of C.occidentalisleaves $(C O L M F)$ was tested against streptozotocin-induceddiabetic rats and the levels of haemoglobin, glycosylated haemoglobin, hepatic glycogen, lipid peroxidation, antioxidants enzymes (TBARS, HP, SOD, CAT, GPx,VitC,VitE,GSH) and hepatic marker enzymes(ALT, AST,ALP,ACP) evaluated in normal and diabetic experimental rats.

Oral administration of COLMFsignificantly and dosedependently normalized the above mentioned parameters near to normal inSTZ-diabetic rats $(\mathrm{p}<0.05)$. Histopathological examination also showed that COLMF extract protected the pancreatic tissue from STZ-induced damage (Emmanuel et al., 2010).

\section{Toxicity}

Vashishtha et al. (2009) showed that the beans and pods are toxic to farm animals. The extent of the toxin depends largely on the dose of the bean consumed.

\section{Sida acutaBurm.f. (Malvaceae) \\ Common name: Horn beam-leafed tree Description}

This plant grows up to $0.7 \mathrm{~m}$ high, branchlets erect, numerous; obovate, dentate broad, and pubescent. Flowers are axillary, solitary or geminate sometimes with a terminal pauciflorousglomerule; fruits more or less globular, covered on top with golden hair; seeds are obovoid and blackish. The plant is a pan tropical wild species, that growing at road sides and on wastelands (Mshana et al., 2000).

Parts used: Whole plant, leaves, roots and shoot.

\section{Medicinal uses}

The whole plant is used for prenatal care and dystocia, while the leaves are for dystocia, diabetes mellitus, lumbago and ringworm. The roots are used to treat dysentery, dystocia, male sexual impotence while the shoot is used for gonorrhoea and male sexual impotence. The leaves are also used to treat abdominal pain, haemorrhoids, azoospermia and oligospermia (Mshana et al., 2000). The effect of the aqueous and methanol extracts of S.acuta on blood glucoselevels in both normal and diabetic rabbits was studied in glucose overloaded rabbits. Extracts have also tested for anti-diabetic activity in alloxan-induced diabeticrabbits.Results showed that both the aqueous extracts of S.acuta (AESA) and the methanol extracts (MESA) at $400 \mathrm{mg} / \mathrm{kg}$ significantly increased the tolerance forglucose in glucose fed normal rabbits. Blood glucose levels were reduced significantly at $11 / 2 \mathrm{hrs}$ post-glucose load $(\mathrm{p}<0.05)$.

This reduction was consistent and persisted to $21 / 2 \mathrm{hrs}$. The positive control drug (glibenclamide, $0.5 \mathrm{mg} / \mathrm{kg}$ body weight, p.o)produced significant reduction on glycemia at 2 hours post glucose load $(\mathrm{p}<0.01)$. The methanol extract produced a significantly lower glucose concentration(mg.min/dl), as calculated from the area under the curve (AUC) of the glucosetolerance test, than AESA, glibenclamide and negative 
control respectively in thetime periods 30-60 minutes, 6090minutes and 90-150minutes ( $<<0.05 ; \mathrm{p}<0.01)$. Both extracts (AESA and MESA) reduced blood glucose level in alloxanized rabbitssignificantly $(\mathrm{p}<0.05)$.

The AESA and MESA (400mg/kg p.o) produced significantdecreases in blood sugar at 4hours with percentage glycemic change of $30 \%$ and $20 \%$ respectively. The antihyperglycemic action of AESA and MESA weresustained up to 8hours with significant percentage glycemic change of $46 \%$ and $45 \%$ respectively $(\mathrm{p}<0.01)$. The crude leaf extracts of Sida acutatherefore possess anti-hyperglycemic activity (Okwuosa et al., 2011).

\section{VernoniaamygdalinaDelile (Asteraceae) \\ Common name: Bitter leaf \\ Description}

A shrub of $2-5 \mathrm{~m}$ high, leaves are elliptic with characteristic bitter taste.

\section{Part Used: Leaves}

Medicinal Uses

The bitter leaf is used in local medicine to cure fever, cough and as a laxative. Leaf decoction is taken to treat pneumonia, increase breast milk in nursing mothers and to cure cough. The leaf juice treats ring worm and other skin infections. When drunk, it treats diabetes. Leaf extract is drunk to cure malaria, fever and intestinal complaints. The infusion of the leaf treats loss of appetite (Obute and Adubor, 2007). A decoction from a combination of herbs is commonly used in Traditional African Medicine for the management of chronic ailments. In Nigeria, the leaves of V.amygdalina Del. (VA) and Azadirachtaindica A. Juss (AI) are used traditionally as a remedy against diabetes mellitus for which empirical evidence attests to its efficacy(Atangwho et al., 2012).

\section{Catharanthus roseus (L.) G. Don (Apocynaceae) \\ Common name: Madagascar periwinkle Description}

It is a procumbent herb that can grow up to a height of 1 $\mathrm{m}$. The leaves are opposite, oval to oblong, green and have short petiole. The flowers are white to dark pink, with five petals lobed together and the fruit exist as a pair of follicles (Gajalakshmi et al., 2013).

Parts used: Whole plant, leaf and root.

Medicinal uses

The whole plants treats muscle pains, sore throat, gastritis, raised blood sugar level, malaria and has anticancer properties. The leaves are used traditionally to treat Hodgkin's lymphoma, and leukaemia. The roots are used to treat high blood sugar (Gajalakshmi et al., 2013).In a study to evaluate the possible antidiabetic and hypolipidemic effect of $C$. roseus leaf powder in diabetic rats, decreased plasma glucose and an increase in plasma insulin were observed after 15 days in diabetes-treated rats and by the end of the experimental period the plasma glucose had almost reached the normal level, but insulin had not. The significant enhancement in plasma total cholesterol, triglycerides, LDL and VLDL-cholesterol, and the atherogenic index of diabetic rats were also normalized in diabetic-treated rats (Rasineni et al., 2010)

\section{Amaranthus viridis L. (Amaranthaceae) \\ Common names: Slender Amaranth or Green Amaranth (Krishnamurthy et al., 2011). \\ Description}

A. viridis grows annually as an erect, monoecious herb, and is around 100-300 cm tall (Krishnamurthy et al., 2011).

Parts used: Whole plant.

\section{Medicinal uses}

A. viridis has been reported to have anti-inflammatory, antipyretic, antirheumatic, antiulcer, antiemetic, antidiabetic, diuretic, analgetic, laxative, antileprotic and hypolipidemic properties. The plant has been used in India traditionally to reduce labour pain, treat respiratory and eye problems, asthma and used for the improvement of appetite (Krishnamurthy et al., 2011).A study was conducted to investigate the antihyperglycemic and hypolipidemic effects of methanolic extract of leaves of $A$. viridis (MEAV) in normal and streptozotocin (STZ) induced diabetic rats.

The statistical data indicated a significant increase in the body weight, decrease in the blood glucose, total cholesterol and serum triglycerides after treatment with MEAV. High density lipoprotein (HDL) cholesterol level was significantly increased when treated with extract. Histologically, focal necrosis was observed in the diabetic rat pancreas, however, was less obvious in treated groups. The MEAV has beneficial effects in reducing the elevated blood glucose level and body weight changes, and improves the lipid profile of STZ induced rats (Krishnamurthy et al., 2011).

\section{Toxicity}

The pollen grains from this plant are known to be highly allergenic and a potential cause of respiratory allergic diseases (Hasnain et al., 2007).

\section{Euphorbia prostrataAiton (Euphobeaceae)}

Common name: Prostrate sandmat, red euphorbia, prostrate spurge (www.flowersofindia.net).

\section{Description}

E. prostrata (L) is an annual herb with slender prostrate, purple-tinted stems up to about $20 \mathrm{~cm}$ long. The oval-shaped leaves are up to $1 \mathrm{~cm}$ long with finely toothed edges. The inflorescence is a cyathium with white petal-like appendages surrounding the actual flowers. There are four male flowers and a single female flower, the latter developing into a lobed, hairy fruit (www.flowersofindia.net).

Parts used: Whole plant.

\section{Medicinal value}

E. prostrate has been reported to have antihemorrhoidal, anti-inflammatory, analgesic, hypolipidemic, antidiabetic, antidiarrheal, antiasthmatic and astringent properties. It also has antioxidant, haemostatic, antithrombotic and vasoprotective 
actions for various skin diseases and used traditionally as snake bite remedy. It is effective against various signs and symptoms of haemorrhoids including bleeding, anal discomfort, anal itching, pain at prolapse and proctitis in haemorrhoids (Sharma et al., 2011).

The active constituents of Euphorbia prostrata include tannins, flavonoids such as apigenin, luteolin and quercetin. It also contains phenolic acids such as ellagic acid, gallic acid (Sharma et al., 2011). Hypolipidaemic evaluations of $E$. prostate observed a deduction to near normal increased cholesterol levels; from 940.7 to $230.41 \quad(75.55 \%)$ and further to $119.2(87.32 \%)$ by the end of the experiment. Similarly, phospholipids and triglycerides levels were reduced. The tissues lipids profiles of liver and heart muscle showed similar changes in those noticed in serum lipids. (Shahwan et al., 2009).

\section{CONCLUSION}

Sixteen plants which are considered as weeds have medicinal values. These plants belong to about 10 families. The whole plant or different parts of the plants such as roots, stem, flowers, leaves, fruits and seeds are used as medicine. Apart from serving as anti-diabetic and anti-hyperlipidaemic, they are used in the treatment of other various diseases such as dysuria, wounds, jaundice, diarrhoea, skin diseases, malaria, gonorrhoea, toothaches, eye problems, asthma, among others. Most of these weeds are edible and are used as vegetables. It can finally be concluded that weeds are valuable medicines and should be protected.

The awareness of the medicinal values of weeds should be made in order to help in the conservation of these plants.

\section{REFERENCES}

Aguh BI, Nock IH, Ndams IS, Agunu A, Ayeku PO.Hypolipidaemic properties of Bauhinia rufescens in alloxan-induced diabetic rats. Scientific Journal of Biological Sciences, 2013; 2(4): 68 - 75

Akah PA, Uzodinma SU, Okolo CE. Antidiabetic activity of aqueous and methanol extract and fractions ofGongronema latifolium (Asclepiadaceae) leaves in alloxandiabetic rats. Journal of Applied Pharmaceutical Sciences, 2011; 1(9): 99 - 102

Anushia C, Sampathkumar P, Ramkumar L. Antibacterial and antioxidant activities of Cassia auriculata. Global Journal of Pharmacology, 2009; 3(3): 127-130.

Atangwho IJ, Ebong PE, Eyong EU, Asmawi MZ, Ahmad M. Synergistic antidiabetic activity of Vernoniaamygdalins and Azadirachtaindica; biochemical effects and possible mechanism. Journal of Ethnopharmacology, 2012; 141(3): 878 -887

Attawish A, Chivapat S, Chavalittumrong P, Phadungpat S, Bansiddhi J, Chaorai B. Chronic toxicity study of Hyptis suaveolens $(\mathrm{L}$. Poit in rats. Songklanakarin J. Sci. Technol, 2005; 27(5): 1027-1036.

Das SN, Ray B, Mahapatra SK, Pothal RK. Microbiological potentiality of Ipomoea sepiariaRoxb (Convolvulaceae). International Journal of Research in Pharmaceutical and Biomedical Sciences, 2011; 2(2); 500-502.

DeshmukhSS. Preliminary phytochemical screening of Hyptis suaveolens (L). Poit leaves. Journal of Current Pharmaceutical Research, 2012; 10 (1): 25-27.
Desu BSR,Saileela CH. Anti-hyperlipidemic activity of methanolic extract of Rhinacanthus nasatus. International Journal of Research in Pharmacy and Chemistry, 2013; 3(3); 2231-2781

Doss A,Anand S. Antihyperglycemic activity of methanol and aqueous extracts of Pergulariadaemia Linn. African Journal of Biotechnology, 2014; 12(1): 170 - 174

Ediriweera ERHSS. A review on medicinal uses of weeds in Sri Lanka. Tropical Agricultural Research and Extension, 2007; 10: 11-16

Emmanuel S, Rani MS, Sreekanth, MR. Antidiabetic activity of Cassia occidentalis Linn. In streptozotocin-induced diabetic rats: A dose dependent study. International Journal of Pharma and Bio Sciences, 2010; 1(4): B14 - B25.

Fu PP, Yang YC, Xia Q, Chou MC, Cui YY, Lin G.Pyrrolizidine alkaloids-tumorigenic components in Chinese herbal medicines and dietary supplements. Journal of Food and Drug Analysis, 2002; 10(4), 198-211.

Gajalakshmi S, Vijayalakshmi S, Rajeswari DV. Pharmacological activities of Catharanthus roseus: aperspective review. International Journal of Pharma and Bio Sciences, 2013; 4(2): 431 -435 .

Gupta AK, Ganguly P, Majumder UK, Ghosal S. Antidiabetic and antihyperlipidaemic effects of Solanumxanthocarpum total extract in alloxin induced diabetic rats. Pharmacologyonline, 2009; 1, 487 - 497

Hasnain M, Fatima K, Al-Frayh A, Saudi A. Prevalence of airborne allergenic Amaranthus viridis pollen in seven different regions of Saudi Arabia. Syed. Med, 2007; 27(4):50-51.

Hawaiian Ecosystem at risk project. Available at: http://www.hear.org/pier/species/urena_lobata.htm. [Accessed 06 November 2013]

Khan V, Najmi AK, Akhtar M, Aqil M, Mujeeb M, Pillai KK. A pharmacological appraisal of medicinal plants with antidiabetic potential.Journal of Pharmacy and BioAllied Sciences, 2012;4(1): 27-42.

Kim HR, Yoon NY, Chung HY, Choi JS. Anti-hyperlipidaemic effect of an edible brown algae, Eckloniastolonifera and its constituents on poloxamer 407-induced hyperlipidaemic and cholesterol-fed rats. Archives of Pharmacal Research, 2008; 31(12), 1564-1571.

Krishnamurthy G, Lakshman K, Pruthvi N, Chandrika PU. Antihyperglycemic and hypolipidemic activity of methanolic extract of Amaranthus viridis leaves in experimental diabetes. Indian Journal of Pharmacology, 2011; 43(4): 450 - 454

Lewu FB, Afolayan AJ. Ethnomedicine in South Africa: the role of weedy species. Afr J Biotech,2009, 8:929-934.

Malavidhane TS, Wickramasinghe SM, Perera MS, Jansz ER. Oral hypoglycaemic activity of Ipomoea aquatica in streptozotocininduced diabetic wistar rats and type II diabetics. Phytotherapy Research, 2003; 17(9): 1098 - 1100

Maroyi A. The gathering and consumption of wild edible plants in Nhema communalarea, Midlands province, Zimbabwe. Ecol Food Nutr, 2011; 50:506-525.

Mazid M, Taqi AK, Firoz M. Medicinal plants of Rural India: A review of Use by Indian Folks. Indo Global Journal of Pharmaceutical Sciences, 2012; 2(3); $286-304$.

Mishra SB, Verma A, Mukerjee A, Vijayakumar M. Antikyperglycemic activity of leaves extract of HypticsuaveolensL.Poit in streptozotocin-induced diabetic rats. Asian Pac J Trop Med, 2011; 4(9): $689-693$.

MshanaNR, Abbiw DK, Addae-Mensah I, Adjanouhoun E, Ahyi MRA, Ekpere JA, Enow-Orock EG, Gbile ZO, Noamesi GK, Odei MA, Odunlami H, Oteng-Yeboah AA, Sarpong K, Safowora A, Tackie AN. Traditional medicine and Pharmacopoiea contribution to the revision of ethnobotanical and floristic studies in Ghana.OAU/STRC.

Muhammad A, Sirat HM. Cox-2 inhibitors from stem bark of Bauhinia rufescens Lam. (Fabaceae). EXCLI Journal, 2013; 12, 824-830.

Nnodim J, Emejulu A, Ihim A, Udujih HI. Influence of Gongronema latifolium on some biochemical parameters in alloxan induced diabetes. International Journal of Analytical, Pharmaceutical and Biomedical Sciences, 2012; 1 (1), 13-17. 
Nyunai N, Manguelle-Dicoum A, Njifutie N, Abdennebi E, Gerard C. Antihyperglycaemiceffect of Ageratum conyzoides $\mathrm{L}$. fractions in normoglycaemic and diabetic male Wistarrats. International Journal of Biomedical and Pharmaceutical Sciences, 2010; 4(1): $38-42$.

ObuteGC, Adubor GO. Chemicals detected in plants used for folk medicine in South Eastern Nigeria. Ethnobotanical Leaflets, 2007; 17(1): $173-194$.

Okwuosa CN, Azubike NC, Nebo II. Evaluation of the antihyperglycaemic activity ofcrude leaf extracts Sida acuta in normal and diabetic rabbits. Indian Journal of Novel Drug Delivery, 2011; 3(3): 206 213.

Pari L,Latha M. Effect of Cassia auriculata flowers on blood sugar levels, serum and tissue lipids in streptozotocin-induced diabetic rats. Singapore Med J, 2002; 43(12): 617 - 621 .

Philippine Medicinal Plants. Available at http://www.stuartxchange.com/Dalupang.html [Accessed 03 November 2013]

Plant Resources of Tropical Africa. Available at http://www.database.prota.org/PROTAhtml.

[Accessed 02 November 2013]

Rasineni K, Bellamkonda R, Singareddy SR, Desireddy S. Antihyperglycaemic activity of Catharanthus roseus leaf powder in streptozotocin-induced diabetic rats. PharmacognosyResearch, 2010; 2(3): 195-201.

Sadiq SI, Shuaibu M, Bello AB, Tureta SG, Isah A, Izuagie T, Nasiru S, Kamaru MB. Phytochemistry and antimicrobial activities of Cassia occidentalis used for herbal remedies. Journal of Chemical Engineering, 2012; 1(1):38-40

Sahu TR. Less known uses of weeds as medicinal plants. Ancient Science of LIFE, 1983; 3(4), 245-249.

Sayani M, Ashok BK, Nishteswar K. Phytochemical and antifungal studies on root of Ipomoea sepiariaKoenig ex. Roxb.. Global Journal of Research on Medicinal Plants \& Indigenous Medicine, 2012; 1 (8): $372-380$

Shahwan MJ, Al-Qirim TM, Daradka H. Hypolipidaemiceffects of Euphorbia prostate in rabbits. Journal of Biological Sciences, 2009; 9(1): $88-91$.

Sharma SK, Joginder SJ, Singh S. Pharmacognostical and phytochemical investigation of Euphorbia prostrataAIT. International Journal of Pharmaceutical Sciences and Research, 2011; 3(4): 1043-1048.
Shetti AA, Sanakal RD, Kaliwal BB. Antidiabetic effect of ethanolic leaf extract of Phyllanthusamarus in alloxan-induced diabetic mice. Asian Journal of Plant Science and Research, 2012; 2(1): 11 - 15

Sindhu T, Rajamanikandan S, Ragavendran P, Sophia D, Meenakshi P, PriyaDurgaD, Gopalakrishnan VK. Antidiabetic activity of Mollugo nudicaulisagainst alloxan induced diabetic rats. IJABPT, 2010; 1(3):511-519.

SrivastavaV, Sharma A, Alam I. A review on ethnomedical and traditional uses of Mimosa pudica (Chui-mui). International Research Journal of Pharmacy, 2012; 3(2): 41 - 44.

Suresh Kumar SV, Mishra SH. Hepatoprotective effect of Pergulariadaemia (Forsk.) ethanol extracts and its fractions. Indian Journal of Experimental Biology, 2008; 46: 447 - 452.

Sutar NG, Sutar UN, Behera BC. Antidiabetic activity of the leaves of Mimosa pudica Linn. in albino rats. Journal of Herbal Medicine and Toxicology, 2009; 3(1): 123 - 126.

Vashishtha VM, John TJ, Kumar A. Clinical and pathological features of acute toxicity due to Cassia occidentalisin vertebrates. Indian J Med Res, 2009; 130: 23-25.

Xavier JR, Gnanam R, Murugan MP, Pappachan A. Clonal propagation of Phyllanthusamarus: A hepatoprotector. Pharmacognosy Magazine, 2012;8(29): 78-82.

YadavaNR, Satnami DK. Chemical Constituent of Cassia occidentalis Linn. Indian Journal of Chemistry, 2011; 50: 1112-1117.

Global Plants. Available at http//www.plants.jstor.org/upwta/1_134 [Accessed 02 November 2013]

\section{How to cite this article:}

Christopher Larbie, Dennis Torkornoo and Jeffrey Dadson. AntiDiabetic and Hypolipidaemic Effect Of Botanicals: A Review of Medicinal Weeds on Knust Campus, Kumasi. J App Pharm Sci, 2014; 4 (10): 097-104 